\title{
Monuments and memorials on SADF ground
}

\section{SA Intelligence School Monument and Memorial Needle}

\section{Introduction}

1. The SA Intelligence School has within its lines both a monument and a memorial needle. These will be individually discussed below in terms of description, history and symbolism.

\section{Monument}

2. The monument (see photos 1, 2, 3 and 4) was erected in remembrance of members of the unit who died whilst serving in the operational area. It stands in front of the National Servicemen's Club in view of the unit $\mathrm{HQ}$ and the rest of the administrative facilities of the unit.

3. Description. The monument is composed of a composite material which has a granite-like appearance. It is made up of six varied size and shape blocks standing one on top of the other. It is erected on a castle-shaped surface of interlocking bricks inlaid with a mosaic of the unit emblem (the flaming dagger). The four faces are described as follows:

\section{1.}

(i) Memorial Needle foreground

(ii) Monument background

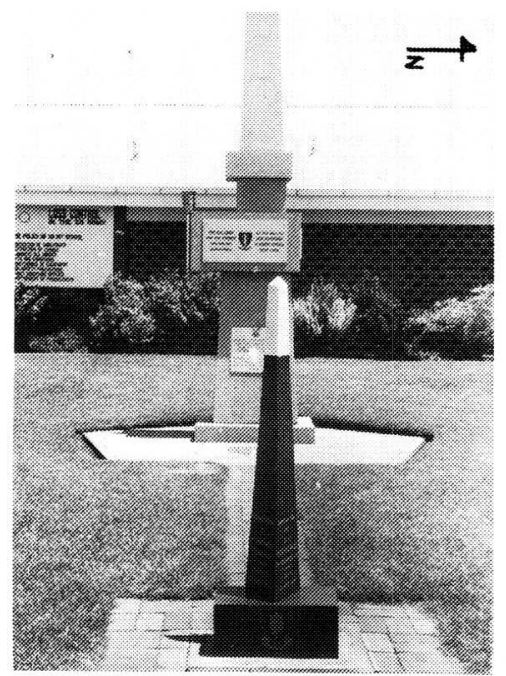

Visible

(i) Memorial Needle

1. Unit emblem and motto: East face

2. Inscriptions North and South faces

3. White marble tip.

(ii) Monument

1. Extract from Scripture: East face

2. Extract from National Anthem: East face

3. Torch of Office: South face.

(iii) Background: National Servicemen's Club.

2

\section{Monument}

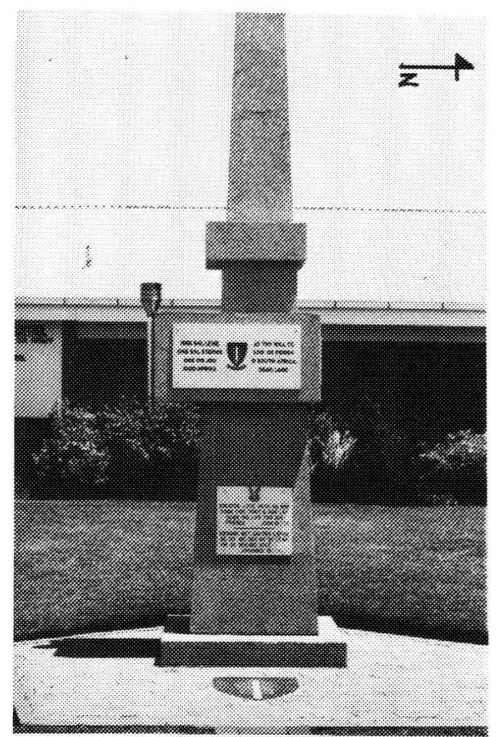
Visible
(i) Mosaic of unit emblem: Ground surface
(ii) Extract from Scripture: East face
(iii) Extract from National Anthem: East face
(iv) Torch of Office: South face
(v) Symbolic shape of rifle
(vi) Background: NSM Club 
(a) East face This is also the front face (see photos 1 and 2) and bears the following ornaments:

(i) Centrally placed metal plaque engraved with the unit emblr and the inscription:

\section{"Ons sal lewe \\ Ons sal sterwe \\ Ons vir jou \\ Suid-Afrika" \\ "At thy will to \\ Live or perish \\ O South Africa \\ Dear land"}

(ii) Lower placed metal plaque embellished with the Corps emblem (the bat-eared fox) and the words of John chapter 15 verse 13 in English and Afrikaans.

(b) North face (Photo 4) This face bears the following ornaments:

(i) A metal plaque commemorating the striking of the first SA Intelligence Corps badge. It is embellished with the actual lead moulding used as an example when authority for the badge was obtained.

\section{Monument}

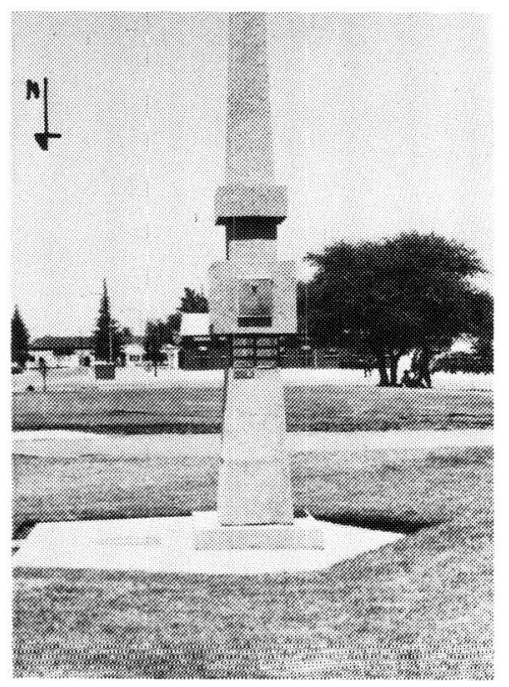

\section{Visible}

(i) Small plaques of 7 intelligence dead: North face

(ii) Plaque commemorating Corps badge

(iii) Background: Leisure Time Utilisation hall (ii) Seven small brass plaques each embellished with a chrome corps badge in memory of the seven corps members who have died whilst serving in the Operational Area since the inception of the SA Intelligence Corps.

(c) South face (Photo 3) This face bears the following ornaments:

(i) A brass torch resting in a chrome holder (usually locked into position). This is the torch of officer presented to the Officer Commanding when assuming command.

3

\section{Monument}

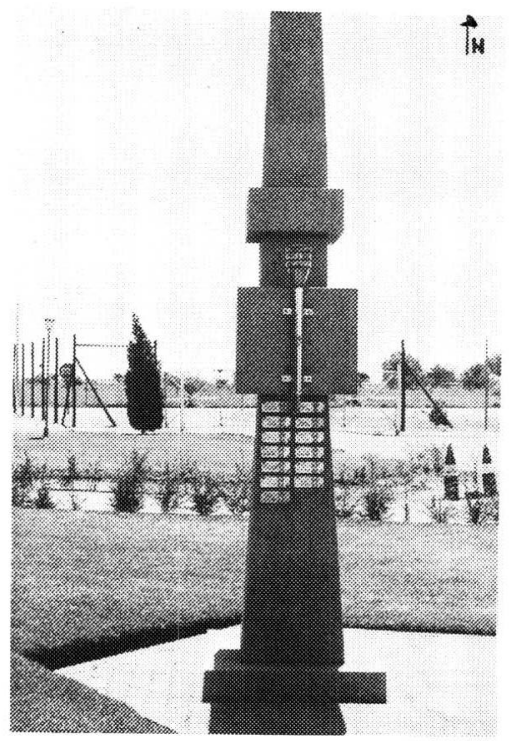

\section{Visible}

(i) Small plaques of 13 infantry dead: South face

(ii) Torch of Office. South face

(iii) Background: Newly planted hedge.

(ii) Thirteen small brass plaques, each embellished with an Infantry Corps badge in memory of the thirteen unit members who died whilst serving in the Operational Area, during the time when SA Intelligence School was still an infantry battalion named 11 Commando.

(d) West face Unadorned. 
4. History The monument was commissioned and erected in 1977. At this time the unit was called 11 Commando. It was the newest of the infantry battalions having been established in January 1974. As an infantry battalion the unit had a constant operational obligation resulting in the inevitable loss of life common to military operations. The sole purpose of the monument at that stage was to commemorate those that died.

5. Initially the East face was the only one which was adorned with any plaques or other symbols. All it had was a metal plaque with the words from the National Anthem and a large metal plaque engraved with the names of those that died during this infantry period. The disadvantage was that every time one of the unit members was killed, the plaque had to be removed for engraving.

6. In 1982 this large plaque was removed and replaced on the South face with individual small plaques for the dead of the infantry period, and on the North face with individual small plaques for the dead of the intelligence period. The plaque with the verse from Scripture was added to the East face at this time.

7. 1982 was the year in which 11 Commando was disbanded and replaced by the SA Intelligence School (although the unit had already ceased to train infantrymen since 1980). To commemorate this occasion the Torch of Office was added to the South face and the plaque of the original Corps badge to the North face.

8. Symbolism. The design of the monument symbolises a rifle standing vertically on its butt. It stands on a surface in the shape of a castle, which is the symbol of the Defence Force. Inlaid in this castle is a mosaic of the unit emblem.

9. The unit emblem is a flaming dagger. Briefly, the symbolism is described as follows:

(a) At the time when 11 Commando was established (1974), the Commando role was to protect the immediate border and interior of the RSA from infiltration by undesirables.

(b) The dagger in the emblem is the international commando dagger although SA Commando perhaps do not operate in the same manner as commandoes in other countries.

(c) St Peter reputedly guards the gates of paradise with a flaming sword to ensure that no undesirables enter.

(d) Therefore, we have a flaming commando dagger guarding the RSA from outsiders. (11 Commando, although an infantry battalion, was originally tasked to feed commando units with personnel once they completed National Service as infantrymen here).

(e) The motto "Per Gadium" is Latin for "By the Sword", which is very appropriate in the light of the foregoing.

(f) The new unit, SA Intelligence School, decided to retain the emblem but to slightly alter the motto to "Lux Ad Gladium", meaning "The Light for the Sword".

(g) This again symbolises the role, as the Intelligence Community has the task of providing "Light" for the teeth arms (traditionally the "Sword") in the form of intelligence regarding the enemy - thus the flames/fire/light around the sword/dagger.

10. The Torch of Office attached to the South face symbolises the role of intelligence in the same way as described in par 9 ( $f$ ) and (g) above. The torch is only lit on ceremonial occasions and when a new Officer Commanding assumes command. It is then handed, burning, to him by the outgoing Officer Commanding.

11. As can be seen from the foregoing the symbolism of the monument as a whole has changed from simply the remembrance of the dead to that, plus the honouring of the Corps and Unit symbols.

\section{Memorial Needle}

12. The memorial needle (see photos 1,5 and 6) was erected to commemorate the disestablishment of 11 Commando and the inauguration of SA Intelligence School. It stands directly in front of the East face of the Monument and these two are connected by a brick pathway. 
13. Description The memorial needle is made of black marble with a white marble tip. The needle itself is three-sided and is mounted on a black marble pedestal. The faces are described as follows:

(a) East face This is also the front face (see photo 1) and simply bears an engraving of the unit emblem and motto.

\section{5}

\section{Memorial Needle}

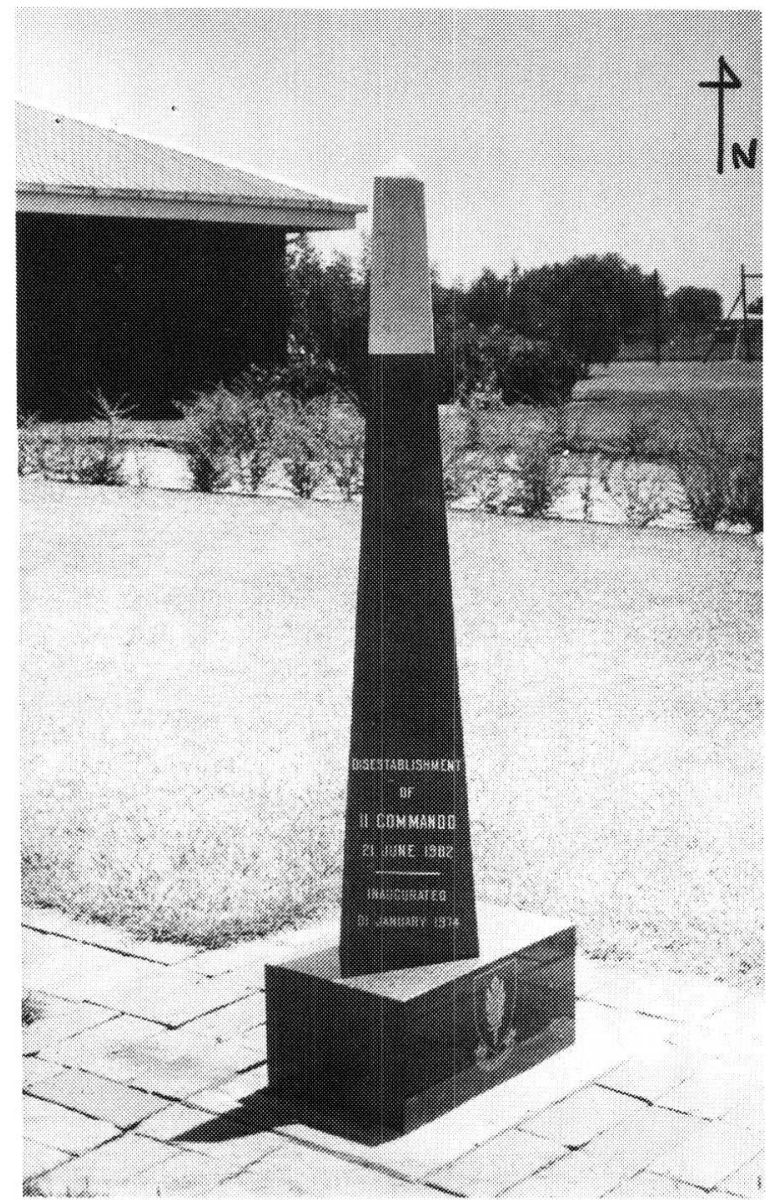

\section{Visible}

(i) Inscription of disestablishment of 11 Commando: South face

(ii) Engraving of unit emblem and motto: East face

(iii) Background: Newly planted hedge

(b) South face Photo 5. This face commemorates the disestablishment of $11 \mathrm{Com}$ mando on 21 June 1982 and mentions also that the unit was inaugurated on 1 January 1974 (c) North face Photo 6. This face commemorates the inauguration of SA Intelligence School on 26 November 1982 and mentions also that the unit was established on 21 June 1982.

\section{Photo 6}

\section{Memorial Needle}

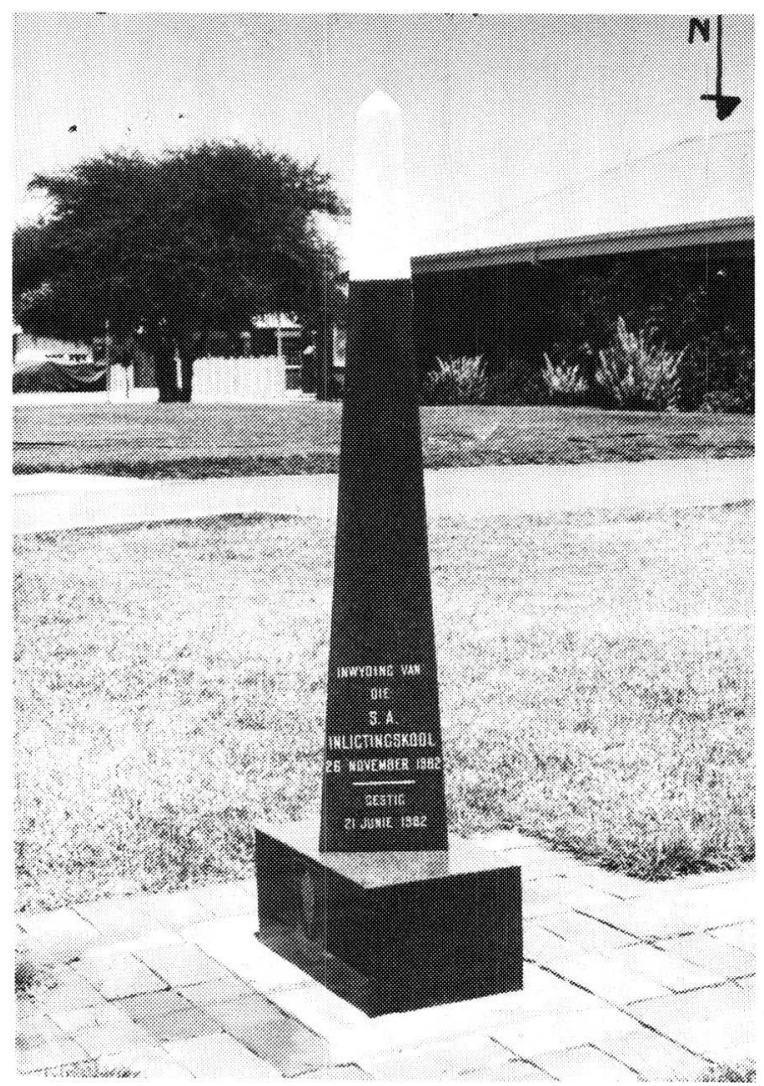

\section{Visible}

(i) Inscription of inauguration of SA Intelligence Service: North face

(ii) Engraving of unit emblem and motto: East face

(iii) Background: NSM Club

14. History The memorial needle was commissioned and erected in 1982. On 26 November of that year it was unveiled by |t-genl P.W. van der Westhuizen, SSA, SM the Chief of Staff Intelligence of the SADF.

15. Symbolism The only significant symbolism attached to the Memorial Needle revolves around the white marble tip. This symbolises the flame of the torch, the shaft of which is naturally the black marble needle itself. This is similar to the Torch of Office attached to the Monument. 


\section{General}

16. Both Monument and Memorial Needle are located on a neat square of lawn surrounded by a hedge (still small but growing) to which access is gained through two gates, one bearing a metal castle (the emblem of the SADF) and the other a bat-eared fox (the emblem of the SA Intelligence Corps).

17. Annually on 31 May a parade is held in front of the Memorial Needle to honour the dead and the foundation of the Republic. This ceremony is usually combined with a medal parade. 